\title{
The Scrutinized-firm Effect, Portfolio Rebalancing, Stock Return Seasonality, and the Pervasiveness of the January Effect in Canada
}

\author{
George Athanassakos \\ Wilfrid Laurier University, Canada, \\ and ALBA, Greece
}

\begin{abstract}
This article examines whether seasonality is present in the excess returns of low risk Canadian firms in safe industries for a sample of firms that are highly scrutinized and visible and uses such tests as the foundation to empirically test competing explanations of stock market seasonality, namely, the tax-loss selling hypothesis and the gamesmanship hypothesis. The tests cover the period 1980 to 1998. For a sample of highly scrutinized and visible firms strong seasonality in excess returns is reported. However, the firms in our sample have unusually low excess returns in January and returns adjust upwards over the remainder of the year. The results hold even after we control for various risk differences among the stocks of our sample. Further, this article's findings imply that the January effect is not as pervasive across risk classes and industry sectors as earlier studies using aggregate data have shown it to be. The disaggregated data of this study provide evidence in support of the gamesmanship hypothesis, but not the tax-loss selling hypothesis. Whenever a January effect is observed, the last quarter of the year tends to be weak for those companies in our sample that experienced a strong January. The opposite is true when a January effect is not evident, as the gamesmanship hypothesis would predict (JEL G14).
\end{abstract}

Keywords: firm visibility, gamesmanship hypothesis, January effect, portfolio rebalancing.

\section{Introduction}

Researchers in Canada, the US and around the world have documented that the average rate of return to stocks in the month of January is

\footnotetext{
${ }^{*}$ The author would like to thank two anonymous referees for suggestions to improve the paper, Bob Leshchyshen formerly of Dominion Bond Rating Service Ltd. for providing part of the bond rating data and also acknowledge the excellent research assistance of John Bagnall, Madhav Hari, Cory Dawe and Catherine Poon. Financial support was provided by a Wilfrid Laurier University Short-Term Research Grant.
}

(Multinational Finance Journal, 2002, vol. 6, no. 1, pp. 1-27)

(CMultinational Finance Society, a nonprofit corporation. All rights reserved.

DOI: $10.17578 / 6-1-1$ 
higher than in any other month of the year. ${ }^{1}$ This phenomenon is known in the Finance literature as the January effect. In the US, the January effect is strictly a small firm phenomenon (see Reinganum [1983] and Keim [1983] among others). While smaller firms tend to outperform larger ones in Canada (see Berges et al. [1984]), and other world markets (see Gultekin and Gultekin [1983]), the January effect is more widespread in these markets than in the US.

Although many explanations have been proposed for the January effect, a universally accepted theory on why it occurs has not yet emerged. ${ }^{2}$ Two hypotheses, however, have received a great deal of attention: the tax-loss selling hypothesis (see Reinganum [1983] and Roll [1983]) and the gamesmanship hypothesis (see Haugen [1990] and Haugen and Lakonishok [1988]). The gamesmanship hypothesis asserts that the high returns on risky securities (generally smaller companies) in the month of January are caused by systematic shifts in the portfolio holdings of professional portfolio managers who attempt to "window dress" or influence performance-based remuneration. Large institutional investors are net buyers of risky securities at the beginning of the year when they are less concerned about including well-known securities in their portfolios or they are trying to outperform benchmarks. By yearend, portfolio managers remove lesser-known, risky, or poorly performing stocks from their portfolios and replace them with well known and less risky (generally larger) stocks with solid recent performance. The excess demand for risky securities at the beginning of the year bids the prices of these securities up. According to the taxloss selling hypothesis, returns are high on some (generally smaller) stocks because tax-loss selling diminishes in January. At year-end investors sell stocks that have fallen in price over the year in order to realize capital losses. The tax-loss selling hypothesis centers on how the behaviour of individual investors affects market dynamics, whereas the focus of the gamesmanship hypothesis is on institutional investors. In

1. See, for example, Rozeff and Kinney (1976), Keim (1983), Brown et al. (1983), Berges et al. (1984), Tinic and Barone-Adesi (1988), Tinic et al. (1987), Kato and Schallheim (1985), and Gultekin and Gultekin (1983).

2. See, for example, Reinganum (1983), Seyhun (1988), Tinic and West (1984), Ritter (1988), Ritter and Chopra (1989), Haugen and Lakonishok (1988) and De Bondt and Thaler (1987). 
either case, the stock of small and risky firms is subject to selling pressure at year-end, which reverses in January and is replaced by buying pressure. However, only the gamesmanship hypothesis further predicts that the average (excess) returns of well-known, safe firms are lower in January as compared to other months of the year.

In this article, we examine whether seasonality is also present in the (excess) returns of low risk firms in safe industries for a sample of firms that are highly scrutinized and visible and use this as the foundation to test competing explanations of the January effect.

We document strong seasonality in excess (market adjusted) returns for a sample of highly scrutinized and visible firms. This seasonality, however, is opposite in direction to that reported for small, less well known, firms (see Keim [1983]). The sample firms command unusually low excess returns in January and excess returns adjust upwards over the remainder of the year. ${ }^{3}$ Even after controlling for size, and various risk considerations, negative excess returns in January tend to persist in our sample firms.

In addition to documenting the impact of firm visibility on stock returns, this article also demonstrates that the January effect is not as pervasive as previous research tended to show. Strong January returns are not documented for all firms independent of the degree of exposure to public scrutiny a firm has received. In addition, January returns are not strong for every sector of the economy or risk class in which the stock belongs.

Finally, this article sheds light to the competing explanations of the January effect by providing support for the gamesmanship hypothesis. Whenever a January effect is observed, the last quarter of the year tends to be weak for those companies in our sample (namely, the least visible) that experienced a strong January. The opposite is true when a January effect is not evident (namely, for the most visible stocks), as the gamesmanship hypothesis would predict. This finding is consistent with other Canadian (see Athanassakos and Schnabel [1994]) and US (see Cuny et al. [1996] and Ackert and Athanassakos [2001]) studies of the gamesmanship hypothesis, which used different data bases and methodology to test for the gamesmanship hypothesis and the January

3. While the firms employed in this article have positive raw returns in January, these returns are much less pronounced than those of less followed firms. 
effect. The above studies performed direct tests of the gamesmanship hypothesis, as they used mutual fund and/or pension fund data in their tests. In an attempt to find corroborating evidence by looking at the question from a different angle, this study offers an indirect test of the competing hypotheses. It looks at the behaviour of stock returns, which have been impacted by the trading of institutional investors, rather than at these investors' trading behaviour directly. Athanassakos and Schnabel (1994) and Cuny et al. (1996) examined all firms in their universe. Ackert and Athanassakos (2001), on the other hand, focussed only on a sample of visible firms, namely firms that were followed by many analysts. As in Ackert and Athanassakos (2001), this article examines a sample of highly visible firms. However, visibility here is proxied by the extent to which a firm has debt rated by Dominion Bond Rating Service of Toronto rather than by the extent to which a firm is followed by analysts.

This article's findings will be particularly useful to institutional investors since portfolio managers' bonus and, indeed, survival are tied to their short-run performance vs. benchmarks for the kind of investment and risk they bear (see, for example, Globe and Mail [1995a, 1995b, 1996] and Business Week [1995]). The cyclical nature of the securities industry and the high turnover of this industry's personnel reinforces such short-term performance evaluation measures. Since the January return usually makes a large part of a portfolio manager's annual return, information (such as the one that is sought after in this article) helping managers do better than average in January can be quite useful.

The rest of the article is organized as follows: section II develops the testable hypotheses. Section III discusses the data and sample characteristics. Section IV discusses the methodology, while section V reports and interprets the findings. Finally, section VI provides the conclusions to the article.

\section{Testable Hypotheses}

Previous research has documented that the January effect is a small firm effect. For example, Keim (1983) finds that roughly one-half of the annual small firm premium documented by Banz (1981) occurred during 
the month of January. This evidence has been corroborated by Blume and Stambaugh (1983), and Haugen and Lakonishok (1988), among others. This small firm effect is consistent with both the tax-loss selling and the gamesmanship hypotheses, as discussed in section I.

In this article, we argue that if the gamesmanship hypothesis is correct, not only should we observe seasonality in the excess returns of small and risky firms, but also in the excess returns of well known and low risk stocks. As portfolio managers rebalance their portfolios away from risky stocks and into low risk stocks in safe industries in order to lock in profits towards year-end, they should bid up the prices of the low risk stocks and down those of high-risk stocks towards year-end. The opposite effect on stock prices should be expected at the beginning of the year as portfolio managers rebalance their portfolios towards higher risk stocks and away from lower risk stocks at that time. Thus, we expect to observe seasonality in excess returns for a sample of firms that are well known and low risk that is opposite of any seasonality that is observed for smaller and high risk stocks. On the other hand, if the January effect results from tax-loss selling, we expect to find little seasonality in the stock returns of well-known and low risk firms. Taxloss selling is associated with individual investors who tend to hold low capitalization stocks (see Ritter [1988]). Institutional investors, on the other hand, concentrate their portfolios on larger, safer companies (see Blume and Friend [1986]). Thus, in general, the stock of well-known and low risk firms should not be subject to any buying or selling pressure for the purposes of tax-loss selling. Our research hypothesis is:

$\mathrm{H}_{0:}$ There is no seasonal pattern in the excess returns of highly scrutinized firms.

To test this hypothesis, we choose a sample of highly scrutinised firms. We use firms that have bonds outstanding that have been rated by Dominion Bond Rating Service Ltd. of Toronto (DBRS) in order to differentiate highly scrutinised firms from those that are not. ${ }^{4}$ Both bond rating agencies and stock analysts evaluate publicly traded companies and communicate their findings and opinions to investors. Evidence shows that both provide new information to the market (see Ederington

4. The relative quality of bonds traded in Canada is judged to some extent from bond ratings given by Dominion Bond Rating Service Ltd. of Toronto or Standard and Poor's (formerly, the Canadian Bond Rating Service Ltd. of Montreal). 
and Goh [1998]). Earlier research looked primarily at analyst following as a proxy for visibility (see Brennan et al. [1993], Brennan and Subrahmanyam [1995] and Ackert and Athanassakos [2002]) or media coverage (see Falkenstein [1996]). We proxy visibility by the extent to which a company has debt rated by DBRS. Evidence provided by Ederington and Goh (1998) demonstrates that bond rating agencies obtain and analyze information faster than analysts and that bond rating agencies expend more resources in detecting deteriorations in a firm's financial position. Furthermore, rating agencies appear to receive inside information unavailable to stock analysts such as minutes of board meetings, profit breakdowns by product and new product plans (see Ederington and Yawitz [1987]). Because bond rating agencies monitor rated companies closely, mismanagement or lack of information about mismanagement are likely to be less prevalent for those firms that have bonds rated. Thus, in acting as information analyzers and intermediaries, bond rating companies promote firm visibility.

The following subsidiary hypotheses will also be tested to examine the effect of firm size, and risk on the January effect for our sample of highly scrutinized firms and further investigate the pervasiveness of this effect.

$\mathrm{H}_{0}^{1}$ : There is no (differential) seasonal pattern in the excess returns of highly scrutinized firms when ranked based on market capitalization.

Firm capitalization proxies for firm liquidity and risk (see Banz [1981] and Roll [1983]). The less liquid a firm is the higher the effect of investor trading on stock prices. If demand rises in January for stocks, small firm stock prices will be particularly bid up and a strong January effect in these stocks will be observed (see Roll [1983] and Haugen and Lakonishok [1988]).

Therefore, if stock market seasonality is driven by firm size, we should expect a (differential) seasonal pattern in the excess returns of firms based on market capitalization and hence reject the above hypothesis.

$\mathrm{H}_{0}^{2}$ : There is no (differential) seasonal pattern in the excess returns of highly scrutinized firms when ranked based on bond ratings. 
Empirical studies provide evidence that there is close relationship between a company's bond rating and its level of total risk, that current bond ratings do provide information about the relative risk of a company's securities and that rating agencies have acquired a reputation for accurately evaluating and reporting the risks of new bond issues (see Wakerman [1990]). Moreover, Fama and French (1989) argue that as default risk increases (and bond ratings are proxies for default risk), the equity risk-premium should also increase, due to the junior position of equity claims relative to debt claims in bankruptcy. They provide support of this argument using US data.

Therefore, if stock market seasonality is driven by total risk differences among companies, we should expect a (differential) seasonal pattern in the excess returns of firms based on risk classification, where the level of risk is proxied by the bond rating, and hence reject the above hypothesis.

$\mathrm{H}_{0}^{3}$ : There is no (differential) seasonal pattern in the excess returns of highly scrutinized firms when ranked based on betas.

Chopra and Ritter (1989) document a positive relationship between the strength of the January effect in the US and the beta coefficient. They find, however, that the relationship is robust only for the small firm size-sorted portfolios. While work by Fama and French (1992) may have shed some doubt in the validity of beta as a measure of risk, recent evidence supports the positive relationship between expected returns and beta and the use of beta as a measure of risk (see Pettengil, Sundaram and Mathur [1995]).

Therefore, if stock market seasonality is driven by systematic risk differences among companies, in a world that the only risk priced is systematic risk, we would expect a (differential) seasonal pattern in the excess returns of stocks based on beta classification, and hence reject the above hypothesis.

$\mathrm{H}_{0}^{4}$ : There is no (differential) seasonal pattern in the excess returns of highly scrutinized firms when ranked based on industry riskiness.

The Toronto Stock Exchange (TSE) has an industrial classification system based on product (good or service) and business cycle 
TABLE 1. Sample Characteristics

\begin{tabular}{|c|c|c|}
\hline $\begin{array}{l}\text { Dominion Bond Rating } \\
\text { Service Rating }\end{array}$ & $\begin{array}{l}\text { Number of } \\
\text { Observations }\end{array}$ & $\begin{array}{l}\text { Number of Different } \\
\text { Companies per Rating }\end{array}$ \\
\hline \multicolumn{3}{|l|}{ A. Risk Classification } \\
\hline 1. $\mathrm{AAA}$ & 240 & 9 \\
\hline 2. $\mathrm{AA}$ & 3,049 & 35 \\
\hline 3. A & 6,754 & 84 \\
\hline 4. $\mathrm{BBB}$ & 2,796 & 49 \\
\hline Total & 12,839 & 177 \\
\hline $\begin{array}{l}\text { Toronto Stock Exchange } \\
\text { Industry Classification }\end{array}$ & $\begin{array}{l}\text { Number of } \\
\text { Observations }\end{array}$ & $\begin{array}{l}\text { Number of } \\
\text { Companies }\end{array}$ \\
\hline \multicolumn{3}{|l|}{ B. Major Industry Classification ${ }^{a}$} \\
\hline 1. Metals \& Minerals & 768 & 4 \\
\hline 2. Gold \& Precious Metals & 154 & 2 \\
\hline 3. Oil \& Gas & 1,415 & 9 \\
\hline 4. Paper \& Forest Products & 959 & 7 \\
\hline 5. Consumer Products & 1,390 & 9 \\
\hline 6. Industrial Products & 1,785 & 18 \\
\hline 7. Real Estate & 443 & 8 \\
\hline 9. Pipelines & 796 & 5 \\
\hline 10. Utilities & 1,454 & 11 \\
\hline 11. Communications \& Media & 464 & 4 \\
\hline 12. Merchandising & 693 & 4 \\
\hline 13. Financial Services & 2,134 & 16 \\
\hline 14. Conglomerates & 383 & 4 \\
\hline Total & 12,839 & 101 \\
\hline
\end{tabular}

Note: ${ }^{a}$ Industry \#8, Transportation \& Environment, is not represented in our sample, as DBRS rated no companies in that industry.

characteristics. Table 1, Panel B shows the various TSE industry groups. Although this classification system is not perfect, as it groups firms that in many cases are not very homogeneous, it will suffice for our analysis, as long as clear differences in risk characteristics exist between industries (see Hatch and White [1988: 194-195]).

Industry groups differ widely in their risk characteristics as is reported in Reilly and Drzycimski (1974). Their study finds that there is a wide range of risk among different industries and that the risk 
measures over time were reasonably stable. Therefore, although risk measures for different industries show substantial dispersion during a period of time, individual industries'risk measures are stable over time. This means that the analysis of past industry risk is necessary, and that this historical analysis can aid attempts to estimate the future risk of an industry.

Therefore, if an industry classification ranking serves as a proxy for risk, we should expect a (differential) seasonal pattern in the excess returns of stocks based on industry classification, and hence reject the above hypothesis.

\section{Sample Selection and Data}

\section{A. Sample Selection}

This study covers the period January 1980 to December 1998. The sample size studied is limited by the availability of company investment grade bond ratings. Our sample includes company data subject to the following criteria.

(i) All companies have bonds rated by the Dominion Bond Rating Service Ltd., at least, over six consecutive years. ${ }^{5}$

(ii) All companies have stocks traded on the Toronto Stock Exchange (TSE).

(iii) All companies have beta estimates in the Canadian Financial Market Research Centre (CFMRC) data base. ${ }^{6}$

5. Survivorship and selection biases may be introduced by this requirement. Survivorship bias, however, may work against this article's hypothesis, thus strengthening the findings if support for the hypotheses is found. In other words, survivorship bias should introduce positive bias on the January excess return, as our sample stocks, being subject to such bias, should experience higher returns than the benchmark/market portfolio. However, here we hypothesize negative January excess return, as it will be seen later. On the other hand, selection bias is key to this and related research as such studies are attempting to select highly visible stocks.

6. The CFMRC data base is derived from the TSE/Western data base, a joint effort by the Toronto Stock Exchange and the University of Western Ontario Business School. We use the data base's monthly file in this study. Among other financial statistics, this file contains monthly rates of return for all Canadian based common equities in the data base or in any given month, as well as total rates of return for the TSE-300, and two universe indexes, an equally weighted index and a value weighted index, over the period January 1950 to date. 
(iv) All companies are classified under an industry in the Toronto Stock Exchange Index Review.

The final sample contains 12,839 observations for 101 firms representing 13 industries from the 14 industries classified in the Toronto Stock Exchange Review. ${ }^{7}$

\section{B. Data}

The sample encompasses 101 companies with a Dominion Bond Rating Service rating that passed the screening tests over the study period. The industry classifications of the stocks in the sample were obtained from the Toronto Stock Exchange Index Review. The company bond ratings were obtained from the DBRS Historical Index Report, which provides "a summary of long-term issuer credit ratings for Canadian borrowers that issue or guarantee outstanding debt". Some companies appear in more than one rating class as their bond ratings were changed over the study period. Monthly betas, prices, shares outstanding, total stock returns, and returns of the TSE-300 value-weighted and (total universe) CFMRC equally weighted total returns indexes were obtained from the CFMRC data base.

The sample characteristics are reported in table 1, panel A by rating and by TSE-industry classification in table 1, panel B. For the purpose of this study, ratings are quantified by 1 if AAA to 4 if BBB. For the purpose of this study, industry groups are quantified by 1 if Gold \& Precious Metals to 13 if Utilities. Industries are ranked from high to low total risk (i.e., standard deviation of returns) with Gold \& Precious Metals being the most risky industry in our sample and Utilities the lowest risk industry (see table 2 , panel B). ${ }^{8}$

7. One would expect our sample to contain 23,028 observations given the time period and the number of companies in the sample. However, not all company related observations in our sample started and ended at the same time. It all depended on when DBRS started and ended rating a company's debt. Moreover, the CFMRC data base does not report beta estimates for all companies/months in our sample. This limited our sample size to 12,839 observations. Nevertheless, the number of observations per year/month does not vary much over the sample period.

8. Industry \#8 (see table 1), Transportation \& Environment, is not represented in our sample, as DBRS rated no companies in that industry that passed our screening tests over the period covered by our study. 
Table 2 reports median values of key risk and size/price variables of companies in our sample in relation to bond rating and TSE-industry classification over the period covered by the study. The risk variables per rating and TSE-industry classification behave as expected. Given that our sample firms are highly visible, we also see in table 2 that many are large and have relatively high priced stocks. Note, however, that a significant number of sample firms are of small to moderate capitalization. We get some perspective on size by considering the size of all Toronto Stock Exchange firms for the period 1986 and 1993 included in a study by Jog and $\mathrm{Li}$ (1995). The smallest size-quartile for the TSE stocks reported in Jog and $\mathrm{Li}$ (1995) had an average value of CAD \$56.2 million. The smallest size-quartile of our sample firms for the same period ranges from CAD \$2.9 million to CAD \$395.9 million with an average value of CAD \$211.5 million, suggesting that many of our sample firms can be classified as small. Moreover, the overall median market value of our sample firms over the $1980-1998$ period is CAD \$903.3 million with a first quartile of CAD \$351.1 million and third quartile of CAD \$2454.7 million.

\section{Methodology}

To test for stock return seasonality in relation to our $\mathrm{H}_{0}$ hypothesis, the following pooled time-series/cross-sectional dummy OLS regressions are run. ${ }^{9}$

$$
R_{q, t}=a_{0}+\sum_{j=2}^{12} a_{j} D_{q, t}^{j}+e_{q, t}
$$

where $R_{q, t}$ is the total monthly raw or excess (market adjusted, based on the TSE-300 Value Weighted or the CFMRC Equally Weighted Total Return Indexes) stock return for stock $q$ in month $t, D_{q, t}^{j}$ is a dummy variable that is equal to 1 if the current month is month $j$ and equal to zero otherwise. This model identifies the months in which stock returns are unusually high. It tests whether stock returns in a given month $(j=$ 2 to 12) are different from a base month, in this study January. The

9. Pooled regressions are run for the reasons detailed in Beaver et al. (1997), and in order to capture the seasonal behaviour of stock returns over time. 


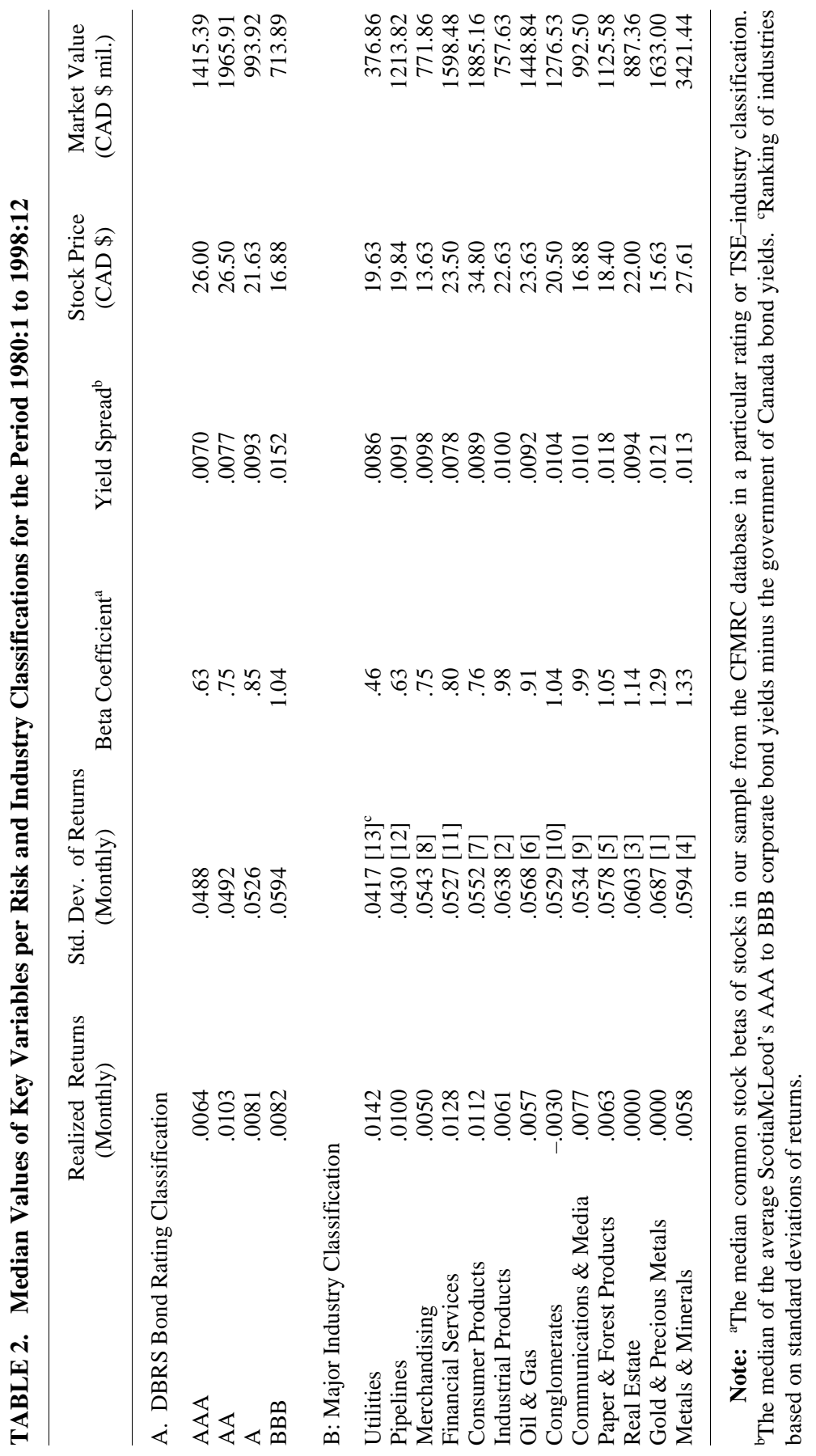


intercept $a_{0}$ indicates the average raw or excess return of stocks in our sample for the month of January. The rest of the coefficients represent the average difference in returns between January and each of the other months.

To test for stock return seasonality in relation to our $\mathrm{H}_{0}^{1}$ to $\mathrm{H}_{0}^{4}$ hypotheses, the following pooled time-series/cross-sectional dummy OLS regressions with interaction terms are run in order to additionally capture portfolio seasonal effects, i.e., the joint effect of the impact of size or risk characteristics on stock raw and excess returns in January and the rest of the year.

$$
R_{q, t}=a_{0}^{*}+\sum_{j=2}^{12} a_{j}^{*} D_{q, t}^{j}+\sum_{j=1}^{12} b_{j} X_{q, t} D_{q, t}^{j}+\varepsilon_{q, t}
$$

This single regression equation is equivalent to using a Zellner's Seemingly Unrelated Regression specification on a set of twelve separate regressions, one per month (see Judge et al. [1985: 800-801]). Such a regression isolates the importance of size or risk characteristics in each month of the year, differentiates each month from each other and associates the firm-size and various risk characteristics of a firm with stock raw or excess returns. Independent variable $X_{q, t}$ stands for market capitalization, beta coefficient, bond rating or TSE-industry classification. ${ }^{10}$ Regression (2) in its various specifications will also test for $\mathrm{H}_{0}$ after controlling for the impact of various portfolio seasonal effects on stock returns.

\section{Empirical Results and Interpretation of Findings}

Table 3 reports the results of OLS dummy variable regressions (regression (1)) for the raw and the two excess (market adjusted) return series employed in this article. ${ }^{11}$ For raw returns the typical seasonal

10. As the results from the regressions run independently may be related, we also run regression (2) where all $X_{q, t}$ variables were included in a single regression. Results and conclusions do not change. Hence, results are not reported in the article but are available upon request.

11. To investigate the robustness of our tests to different definitions of excess returns, we also used risk-adjusted excess returns based on the CAPM, where the market portfolio 
TABLE 3. Tests of Monthly-Seasonal Effects in Raw Returns $\left(\boldsymbol{R}_{j}\right)$ and Excess Returns Against the TSE-300 Value-Weighted $\left(\boldsymbol{R}_{T S E}\right)$ and the CFMRC Equally Weighted $\left(\boldsymbol{R}_{E W}\right)$ Total Returns Stock Indexes

\begin{tabular}{|c|c|c|c|}
\hline Month & $\begin{array}{c}\quad R_{j} \\
\text { Raw Returns }\end{array}$ & $\begin{array}{c}\quad R_{j}-R_{T S E} \\
\text { Excess Returns }\end{array}$ & $\begin{array}{c}R_{j}-R_{E W} \\
\text { Excess Returns }\end{array}$ \\
\hline January & $\begin{array}{c}.0191 \\
(7.97)^{* * *}\end{array}$ & $\begin{array}{c}.0048 \\
(2.23)^{* *}\end{array}$ & $\begin{array}{c}-.0212 \\
(8.72)^{* * *}\end{array}$ \\
\hline February & $\begin{array}{l}.0009 \\
(.29)\end{array}$ & $\begin{array}{l}.0016 \\
(.53)\end{array}$ & $\begin{array}{c}.0191 \\
(5.58) * * *\end{array}$ \\
\hline March & $\begin{array}{l}-.0018 \\
(.53)\end{array}$ & $\begin{array}{l}.0048 \\
(1.60)\end{array}$ & $\begin{array}{c}.0142 \\
(4.14)^{* * * *}\end{array}$ \\
\hline April & $\begin{array}{c}-.0143 \\
(4.22)^{* * *}\end{array}$ & $\begin{array}{l}-.0042 \\
(1.43)\end{array}$ & $\begin{array}{c}.0182 \\
(5.30) * * *\end{array}$ \\
\hline May & $\begin{array}{l}.0018 \\
(.54)\end{array}$ & $\begin{array}{c}-.0076 \\
(2.53)^{* *}\end{array}$ & $\begin{array}{c}.0191 \\
(5.58) * * *\end{array}$ \\
\hline June & $\begin{array}{c}-.0138 \\
(4.11)^{* * *}\end{array}$ & $\begin{array}{l}-.0006 \\
(.19)\end{array}$ & $\begin{array}{c}.0191 \\
(5.58) * * *\end{array}$ \\
\hline July & $\begin{array}{c}-.0074 \\
(2.19)^{* *}\end{array}$ & $\begin{array}{l}-.0097 \\
(3.23)^{* * *}\end{array}$ & $\begin{array}{c}.0243 \\
(7.09) * * *\end{array}$ \\
\hline August & $\begin{array}{c}-.0058 \\
(1.71)^{*}\end{array}$ & $\begin{array}{l}-.0043 \\
(1.42)\end{array}$ & $\begin{array}{c}.0134 \\
(3.97)^{* * *}\end{array}$ \\
\hline September & $\begin{array}{l}-.0327 \\
(9.67)^{* * *}\end{array}$ & $\begin{array}{l}-.0048 \\
(1.60)\end{array}$ & $\begin{array}{c}.0243 \\
(7.07) * * *\end{array}$ \\
\hline October & $\begin{array}{l}-.0195 \\
(5.75) * * *\end{array}$ & $\begin{array}{l}-.0012 \\
(.39)\end{array}$ & $\begin{array}{c}.0395 \\
(11.57)^{* * *}\end{array}$ \\
\hline November & $\begin{array}{l}.0012 \\
(.35)\end{array}$ & $\begin{array}{l}-.0017 \\
(.56)\end{array}$ & $\begin{array}{c}.093 \\
(2.72)^{* * *}\end{array}$ \\
\hline December & $\begin{array}{l}.0019 \\
(.55)\end{array}$ & $\begin{array}{l}-.0050 \\
(1.64)^{*}\end{array}$ & $\begin{array}{c}.0154 \\
(4.47)^{* * *}\end{array}$ \\
\hline$F-$ Statistic & $20.47 * * *$ & $3.64 * * *$ & $15.26 * * *$ \\
\hline
\end{tabular}

Note: The table reports the results of dummy OLS regressions for a sample of returns of highly scrutinized firms for 1980 through 1998 time period. The table reports ordinary $t$-statistics in parentheses below each estimated seasonal dummy variable and in the final raw $F$-tests of the null hypothesis of no differences across months. *,**, *** significant at the $10 \%, 5 \%$ and $1 \%$ level, respectively.

was defined as the TSE-300 value weighted index, as well as the CFMRC equally weighted index. The results (not reported here but available upon request) were identical to those reported in the article using the market adjusted returns model to estimate excess returns. 
pattern of returns is evident. Returns in January are higher than the remainder of the year. The coefficient for the January dummy is positive and significant and all other dummy variable coefficients are negative, though not all are significant. The $F$-statistic rejects the null hypothesis of no difference across months at the $1 \%$ level of significance. The excess returns of our sample stocks against the TSE-300 value weighted stock index, a relatively comparable group in terms of risk and visibility, also reveal strong January seasonal, though most of the other months do not appear to be significantly different from January. However, the $F$ statistic here too rejects the null hypothesis of no difference across months at the $1 \%$ level of significance. With regards to the excess returns of our sample stocks against the CFMRC equally weighted stock index, which puts more weight on smaller stocks and thus tends to include a relatively less scrutinized and followed on average group of stocks, strong seasonality in excess returns is also documented. ${ }^{12}$ However, this pattern in excess returns is opposite to that reported for a sample of small stocks. Rather than earning positive excess returns in January, the sample of highly scrutinized firms earned negative excess returns. Excess returns adjust upwards over the remainder of the year. The $F$-statistic rejects the null hypothesis of no difference across months at the $1 \%$ level of significance. Thus, we reject the null hypothesis $\left(\mathrm{H}_{0}\right)$ that there is no seasonal pattern in returns of highly scrutinized firms. The pattern of excess returns (against the CFMRC equally weighted stock index) is consistent with the gamesmanship hypothesis.

To investigate whether there exists seasonality by firm size or various risk characteristics in our sample of highly scrutinized firms, we estimate regression (2), which includes (interaction) portfolio seasonal effects in addition to the monthly seasonal dummies. ${ }^{13}$ Each of the

12. The CFMRC equally weighted index gives higher weights to smaller firms, is itself broader based and thus it includes more smaller stocks as opposed to the TSE-300 value weighted index, which is not as broadly based and gives a higher weighting to the stock of larger companies. The TSE-300 value weighted and the CFMRC value weighted indexes gave similar results. Thus we only report the results obtained using the TSE-300 index.

13. To conserve space and focus on the most important portfolio-seasonal effects, we only report interaction term coefficients for the 1st and last quarters of the year in tables 4 to 6 . The remaining coefficients are available upon request. Also, industry \#14 (table 1, panel B), Conglomerates, was excluded from our regression analysis that tests portfolio/seasonal effects based on the TSE-industry classification because there is great difference between companies in this highly diverse group. 
following tables (tables 4-6) contains four columns each reporting the regression coefficients from running regression (2), where independent variable $X_{q, t}$ stands successively for market capitalization, beta coefficient, bond rating and TSE-industry classification. Table 4 reports estimates for the raw return series. In panel A, strong January seasonal is still observed in most of the specifications of regression (2) even after controlling for the portfolio-seasonal effects. However, what is more interesting is that for our sample of highly scrutinized firms, once we control for visibility, firm size has a positive relationship to raw stock returns rather than the negative relationship traditionally found in the US and around the world (table 4, panel A). In table 4, panel B, the regression coefficient for the interaction term between January and market capitalization has a positive (and statistically significant) sign indicating that the larger the firm the higher the January stock returns in our sample of stocks. ${ }^{14}$ With regards to the regression coefficient for the interaction term between January and beta, a positive (and statistically significant) coefficient is documented indicating that the higher the systematic risk, the higher are the stock returns in January. For the TSE-industry classification regression, the January/TSE-industry classification interaction coefficient has a negative (and statistically significant) sign indicating that the riskier the industry in which a firm belongs the higher the January returns. With regards to beta and TSEindustry classification (table 4, panel B), another interesting finding is that for the last few months of the year the sign of the coefficients for the interaction terms reverses from that documented for January. The same pattern is also observed for bond rating, even though the January interaction term is not statistically significant. An explanation for why this sign reversion may happen will be furnished later. All $F$-statistics are statistically significant at the $1 \%$ level of significance. Thus, from the evidence above, we reject the null hypotheses $\mathrm{H}_{0}^{1}$ to $\mathrm{H}_{0}^{4}$.

Tables 5 and 6 report results for excess returns based on the TSE300 value weighted index and the CFMRC equally weighted index,

14. The month/portfolio interaction variables capture the effect of market capitalization, beta coefficient, bond rating and TSE-industry classification on excess returns in a given month of the year. The tests are similar, but more efficient, to sorting our sample firms according to a firm characteristic, forming portfolios and then observing how excess returns vary across the firm characteristic-sorted portfolios in a particular month. 
TABLE 4. Tests of Monthly-Seasonal and Portfolio-Seasonal Effects in Raw Returns

\begin{tabular}{lccll}
\hline $\begin{array}{l}\text { Independent } \\
\text { Variable }\end{array}$ & $\begin{array}{c}\text { Market } \\
\text { Capitalization }\end{array}$ & $\begin{array}{c}\text { Beta } \\
\text { Coefficient }\end{array}$ & $\begin{array}{l}\text { Bond } \\
\text { Rating }\end{array}$ & $\begin{array}{l}\text { TSE-Industry } \\
\text { Classification }\end{array}$ \\
\hline
\end{tabular}

A. Monthly Seasonal Effects

\begin{tabular}{|c|c|c|c|c|}
\hline January & $\begin{array}{c}.0157 \\
(5.63)^{* * *}\end{array}$ & $\begin{array}{l}.0075 \\
(1.13)\end{array}$ & $\begin{array}{l}.0106 \\
(1.06)\end{array}$ & $\begin{array}{c}.0374 \\
(6.75)^{* * *}\end{array}$ \\
\hline \multirow[t]{2}{*}{ February } & .0049 & .0013 & .0048 & -.0107 \\
\hline & $(1.27)$ & $(.14)$ & $(.34)$ & (1.38) \\
\hline \multirow[t]{2}{*}{ March } & .0045 & .0041 & -.0042 & -.0202 \\
\hline & $(1.17)$ & $(.43)$ & $(.30)$ & $(2.61)^{* * *}$ \\
\hline \multirow[t]{2}{*}{ April } & -.0129 & .0099 & .0118 & -.0390 \\
\hline & $(3.30)^{* * *}$ & $(1.06)$ & $(.84)$ & $(5.02)^{* * *}$ \\
\hline \multirow[t]{2}{*}{ May } & .0033 & -.0010 & .0085 & -.0135 \\
\hline & $(.85)$ & $(.11)$ & $(.60)$ & $(1.74)^{*}$ \\
\hline \multirow[t]{2}{*}{ June } & -.0107 & .0023 & .0035 & -.0354 \\
\hline & $(2.74) * * *$ & $(.25)$ & $(.27)$ & $(4.57)^{* * *}$ \\
\hline \multirow[t]{2}{*}{ July } & -.0055 & -.0061 & -.0224 & -.0239 \\
\hline & $(1.41)$ & $(.66)$ & (1.59) & $(3.07)^{* * *}$ \\
\hline \multirow[t]{2}{*}{ August } & -.0005 & .0216 & .0029 & -.0245 \\
\hline & $(.15)$ & $(2.29)^{* *}$ & $(.21)$ & $(3.15)^{* * *}$ \\
\hline \multirow[t]{2}{*}{ September } & -.0312 & .0117 & -.0248 & -.0705 \\
\hline & $(7.95)^{* * *}$ & $(1.24)$ & $(1.75)^{*}$ & $(9.04)^{* * *}$ \\
\hline \multirow[t]{2}{*}{ October } & -.0189 & .0167 & .0151 & -.0615 \\
\hline & $(4.81)^{* * *}$ & $(1.78)^{*}$ & $(1.07)$ & $(7.87)^{* * *}$ \\
\hline \multirow[t]{2}{*}{ November } & .0039 & .0247 & .0120 & -.0244 \\
\hline & $(.98)$ & $(2.65) * * *$ & $(.85)$ & $(3.12)^{* * *}$ \\
\hline \multirow[t]{2}{*}{ December } & .0052 & .0090 & .0012 & -.0260 \\
\hline & $(1.32)$ & $(.95)$ & $(.08)$ & $(3.31)^{* * *}$ \\
\hline \multicolumn{5}{|c|}{ B. Portfolio-Seasonal Effects } \\
\hline January/ & .0000 & .0131 & .0029 & -.0024 \\
\hline Portfolio & $(2.70) * * *$ & $(1.89)^{*}$ & $(.88)$ & $(3.66) * * *$ \\
\hline February/ & -.0000 & .0128 & .0016 & -.0008 \\
\hline Portfolio & $(.19)$ & $(1.89)^{*}$ & $(.49)$ & $(1.26)$ \\
\hline March/ & -.0000 & .0067 & .0037 & .0000 \\
\hline Portfolio & $(1.61)$ & $(.97)$ & $(1.15)$ & $(.02)$ \\
\hline- & - & - & - & - \\
\hline October/ & .0000 & -.0277 & -.0088 & .0033 \\
\hline Portfolio & $(1.81)^{*}$ & $(3.97) * * *$ & $(2.67) * * *$ & $(4.99)^{* * *}$ \\
\hline November/ & .0000 & -.0135 & -.0008 & .0009 \\
\hline Portfolio & $(.65)$ & $(1.93)^{* *}$ & $(.22)$ & $(1.45)$ \\
\hline
\end{tabular}


TABLE 4. (Continued)

\begin{tabular}{lcccc}
\hline $\begin{array}{l}\text { Independent } \\
\text { Variable }\end{array}$ & $\begin{array}{c}\text { Market } \\
\text { Capitalization }\end{array}$ & $\begin{array}{c}\text { Beta } \\
\text { Coefficient }\end{array}$ & $\begin{array}{c}\text { Bond } \\
\text { Rating }\end{array}$ & $\begin{array}{c}\text { TSE-Industry } \\
\text { Classification }\end{array}$ \\
\hline $\begin{array}{l}\text { December/ } \\
\text { Portfolio }\end{array}$ & -.0000 & .0051 & .0032 & .0013 \\
$F-$ Statistic & $(.06)$ & $(.72)$ & $1.95)$ & $(1.97)^{* *}$ \\
& $10.71 * * *$ & $13.12 * * *$ & $10.69 * * *$ & $12.12 * * *$ \\
\hline
\end{tabular}

Note: The table reports the results of dummy OLS regressions for a sample of returns of highly scrutinized firms for 1980 through 1998 time period. Monthly seasonal effects are captured in panel A, which reports coefficients of monthly dummy variables. Portfolio-seasonal effects are captured using interaction terms between the monthly dummies and portfolio formation variables based on market capitalization, beta, bond rating and TSE-industry classification. Regression coefficients for these tests are reported in panel B. The table reports ordinary $t$-statistics in parentheses below each estimated independent variable and in the final raw $F$-tests of the null hypothesis of no differences across months. $*, * *, * * *$ significant at the $10 \%, 5 \%$ and $1 \%$ level, respectively.

respectively. The January seasonal weakens considerably in table 5, panel A after controlling for portfolio seasonal effects. However, all January interaction coefficients are significant in table 5, panel B. The January/portfolio coefficient for the firm size equation, once we control for firm visibility, has positive sign as opposed to the negative sign traditionally documented. The January/portfolio coefficient for the beta regression is positive, the same as for the bond rating regression..$^{15}$ The sign of the January/portfolio coefficient for the TSE-industry classification regression is negative. Notice that again the portfolioseasonal coefficients for beta, rating and TSE-industry classification regressions reverse sign towards the last few months of the year (table

15. Kotoulas and Kryzanowski (1996) find that a multifactor model with time varying risk-premia explains a significant portion of the January seasonality in Canadian data. As a result, to further investigate the robustness of the beta-based findings, the beta-based regression (2) was re-estimated by allowing risk-premia to vary over time. This refinement made the January/portfolio coefficient of the beta regression insignificant without, however, changing its sign. Moreover, while the November/portfolio coefficient has also become insignificant, the above-mentioned refinement has made the December/portfolio coefficient statistically significant, when it was not before. Finally, the October/portfolio coefficient is still significant at the $1 \%$ level of significance. As a result, allowing risk-premia to vary over time did not materially alter the article's overall conclusions regarding seasonality in excess returns of highly scrutinized and visible Canadian firms. These results are not reported in the article but are available upon request. 
TABLE 5. Tests of Monthly Seasonal and Portfolio-Seasonal Effects in Excess Returns Against the TSE-300 Value Weighted Total Returns Index

\begin{tabular}{|c|c|c|c|c|}
\hline $\begin{array}{l}\text { Independent } \\
\text { Variable }\end{array}$ & $\begin{array}{c}\text { Market } \\
\text { Capitalization }\end{array}$ & $\begin{array}{c}\text { Beta } \\
\text { Coefficient }\end{array}$ & $\begin{array}{l}\text { Bond } \\
\text { Rating }\end{array}$ & $\begin{array}{l}\text { TSE-Industry } \\
\text { Classification }\end{array}$ \\
\hline \multicolumn{5}{|c|}{ A. Monthly-Seasonal Effects } \\
\hline January & $\begin{array}{l}.0021 \\
(.84)\end{array}$ & $\begin{array}{l}-.0072 \\
(1.23)\end{array}$ & $\begin{array}{l}-.0130 \\
(1.47)\end{array}$ & $\begin{array}{c}.0231 \\
(4.70)^{* * *}\end{array}$ \\
\hline February & $\begin{array}{l}.0048 \\
(1.40)\end{array}$ & $\begin{array}{l}.0089 \\
(1.09)\end{array}$ & $\begin{array}{l}.0096 \\
(.77)\end{array}$ & $\begin{array}{l}-.0103 \\
(1.49)\end{array}$ \\
\hline March & $\begin{array}{c}.0104 \\
(3.02)^{* * *}\end{array}$ & $\begin{array}{l}.0115 \\
(1.40)\end{array}$ & $\begin{array}{l}.0136 \\
(1.09)\end{array}$ & $\begin{array}{c}-.0148 \\
(2.15)^{* *}\end{array}$ \\
\hline April & $\begin{array}{l}-.0032 \\
(.93)\end{array}$ & $\begin{array}{r}.0154 \\
(1.87)^{*}\end{array}$ & $\begin{array}{c}.0367 \\
(2.93)^{* * *}\end{array}$ & $\begin{array}{l}-.0286 \\
(4.15)^{* * *}\end{array}$ \\
\hline May & $\begin{array}{l}-.0053 \\
(1.54)\end{array}$ & $\begin{array}{l}-.0061 \\
(.74)\end{array}$ & $\begin{array}{l}.0139 \\
(1.15)\end{array}$ & $\begin{array}{l}-.0201 \\
(2.93)^{* * *}\end{array}$ \\
\hline June & $\begin{array}{l}.0014 \\
(.40)\end{array}$ & $\begin{array}{c}.0197 \\
(2.41)^{* *}\end{array}$ & $\begin{array}{l}.0176 \\
(1.42)\end{array}$ & $\begin{array}{l}-.0236 \\
(3.44)^{* * *}\end{array}$ \\
\hline July & $\begin{array}{c}-.0070 \\
(2.03)^{* *}\end{array}$ & $\begin{array}{l}-.0029 \\
(.36)\end{array}$ & $\begin{array}{l}-.0141 \\
(1.31)\end{array}$ & $\begin{array}{c}-.0245 \\
(3.56)^{* * *}\end{array}$ \\
\hline August & $\begin{array}{l}-.0015 \\
(.43)\end{array}$ & $\begin{array}{l}.0081 \\
(.97)\end{array}$ & $\begin{array}{l}.0175 \\
(1.39)\end{array}$ & $\begin{array}{c}-.0254 \\
(3.68)^{* * *}\end{array}$ \\
\hline September & $\begin{array}{l}-.0003 \\
(.08)\end{array}$ & $\begin{array}{c}.0405 \\
(4.87)^{* * *}\end{array}$ & $\begin{array}{c}.0269 \\
(2.15)^{* *}\end{array}$ & $\begin{array}{c}-.0407 \\
(5.90) * * *\end{array}$ \\
\hline October & $\begin{array}{l}-.0002 \\
(.07)\end{array}$ & $\begin{array}{c}.0363 \\
(4.38)^{* * *}\end{array}$ & $\begin{array}{c}.0557 \\
(4.45)^{* * *}\end{array}$ & $\begin{array}{c}-.0412 \\
(5.95)^{* * *}\end{array}$ \\
\hline November & $\begin{array}{l}-.0023 \\
(.67)\end{array}$ & $\begin{array}{l}.0087 \\
(1.05)\end{array}$ & $\begin{array}{l}.0160 \\
(1.13)\end{array}$ & $\begin{array}{c}-.0305 \\
(4.39) * * *\end{array}$ \\
\hline December & $\begin{array}{l}.0022 \\
(.64)\end{array}$ & $\begin{array}{l}.0044 \\
(.54)\end{array}$ & $\begin{array}{l}.0054 \\
(.43)\end{array}$ & $\begin{array}{c}-.0322 \\
(4.62)^{* * *}\end{array}$ \\
\hline B. Portfolio- & sonal Effects & & & \\
\hline $\begin{array}{l}\text { January/ } \\
\text { Portfolio } \\
\text { February/ } \\
\text { Portfolio } \\
\text { March/ } \\
\text { Portfolio }\end{array}$ & $\begin{array}{c}.0000 \\
(2.51)^{* * *} \\
-.0000 \\
(.13) \\
-.0000 \\
(1.98)^{* *}\end{array}$ & $\begin{array}{c}.0134 \\
(2.19)^{* *} \\
.0053 \\
(.89) \\
.0059 \\
(.98)\end{array}$ & $\begin{array}{c}.0060 \\
(2.08)^{* *} \\
.0033 \\
(1.55) \\
.0030 \\
(1.05)\end{array}$ & $\begin{array}{c}-.0024 \\
(4.16)^{* * *} \\
-.0008 \\
(1.38) \\
.0001 \\
(.25)\end{array}$ \\
\hline- & - & - & - & - \\
\hline $\begin{array}{l}\text { October/ } \\
\text { Portfolio } \\
\text { November/ } \\
\text { Portfolio }\end{array}$ & $\begin{array}{c}.0000 \\
(1.15) \\
.0000 \\
(2.90)^{* * *}\end{array}$ & $\begin{array}{c}-.0288 \\
(4.68)^{* * *} \\
.0017 \\
(.29)\end{array}$ & $\begin{array}{l}-.0133 \\
(4.55)^{* * *} \\
-.0001 \\
(.03)\end{array}$ & $\begin{array}{c}.0029 \\
(5.15)^{* * *} \\
.0013 \\
(2.25)^{* * *}\end{array}$ \\
\hline
\end{tabular}


TABLE 5. (Continued)

\begin{tabular}{lcccc}
\hline $\begin{array}{l}\text { Independent } \\
\text { Variable }\end{array}$ & $\begin{array}{c}\text { Market } \\
\text { Capitalization }\end{array}$ & $\begin{array}{c}\text { Beta } \\
\text { Coefficient }\end{array}$ & $\begin{array}{l}\text { Bond } \\
\text { Rating }\end{array}$ & $\begin{array}{c}\text { TSE-Industry } \\
\text { Classification }\end{array}$ \\
\hline December/ & -.0000 & .0028 & .0025 & .0012 \\
Portfolio & $(.20)$ & $(.45)$ & $(.85)$ & $(2.07)^{* *}$ \\
$F-$ Statistic & $4.49 * * *$ & $4.98 * * *$ & $3.71 * * *$ & $4.94 * * *$ \\
\hline
\end{tabular}

Note: The table reports the results of dummy OLS regressions for a sample of returns of highly scrutinized firms for 1980 through 1998 time period. Monthly seasonal effects are captured in panel A, which reports coefficients of monthly dummy variables. Portfolio effects are captured using interaction terms between the monthly dummies and portfolio formation variables based on market capitalization, beta, bond rating and TSE-industry classification. Regression coefficients for these tests are reported in panel B. Excess returns are calculated using the TSE- 300 Value Weighted Total Returns Index. The table reports ordinary $t$-statistics in parentheses below each estimated independent variable and in the final raw $F$-tests of the null hypothesis of no differences across months. *, **, *** significant at the $10 \%, 5 \%$ and $1 \%$ level, respectively.

5 , panel B). ${ }^{16}$

With regards to table 6, we observed a strong January (monthly) seasonal in panel $\mathrm{A}$, which, however, is opposite in direction to the one traditionally documented. Furthermore, there is a strong negative excess return in January for our sample of highly visible firms, no matter whether we control for portfolio seasonal effects using firm size or risk characteristics. In table 6, panel $\mathrm{B}$, we document a positive January/bond rating interaction coefficient, which indicates that the lower the bond rating of a company (i.e., the higher the bond rating number assigned in this article), the higher the average excess return of January over the 1980-1998 period. More importantly, consistent with the gamesmanship hypothesis, there is a negative relationship between excess returns and bond rating for October and November (see the negative October/Portfolio and November/Portfolio interaction coefficients), the opposite from January. The worse the rating, the higher the excess return in January, but the lower the excess return in the last few months of the year. If institutional investors bail out of risky firms toward the end of the year in order to lock in returns and invest into safer firms, the documented negative relationship in the last few

16. As discussed in Section III.B, companies whose bonds have been assigned a rating of 4 are riskier than companies with a rating of 1 . Similarly, companies in industry group with a rank of 1 are riskier than companies in industry group with a rank of 13 . 
TABLE 6. Tests of Monthly Seasonal and Portfolio-Seasonal Effects in Excess Returns Against the CFMRC Equally Weighted Total Returns Index

\begin{tabular}{|c|c|c|c|c|}
\hline $\begin{array}{l}\text { Independent } \\
\text { Variable }\end{array}$ & $\begin{array}{c}\text { Market } \\
\text { Capitalization }\end{array}$ & $\begin{array}{c}\text { Beta } \\
\text { Coefficient }\end{array}$ & $\begin{array}{l}\text { Bond } \\
\text { Rating }\end{array}$ & $\begin{array}{l}\text { TSE-Industry } \\
\text { Classification }\end{array}$ \\
\hline \multicolumn{5}{|c|}{ A. Monthly-Seasonal Effects } \\
\hline January & $\begin{array}{l}-.0240 \\
(8.80)^{* * *}\end{array}$ & $\begin{array}{c}-.0333 \\
(4.95)^{* * *}\end{array}$ & $\begin{array}{c}-.0342 \\
(3.37)^{* * *}\end{array}$ & $\begin{array}{c}-.0111 \\
(2.09)^{* *}\end{array}$ \\
\hline February & $\begin{array}{c}.0249 \\
(6.34)^{* * *}\end{array}$ & $\begin{array}{c}.0363 \\
(3.88)^{* * *}\end{array}$ & $\begin{array}{r}.0269 \\
(1.88)^{*}\end{array}$ & $\begin{array}{l}.0012 \\
(1.50)\end{array}$ \\
\hline March & $\begin{array}{c}.0219 \\
(5.40)^{* * *}\end{array}$ & $\begin{array}{c}.0265 \\
(2.82)^{* * *}\end{array}$ & $\begin{array}{l}.0178 \\
(1.25)\end{array}$ & $\begin{array}{l}-.0034 \\
(.46)\end{array}$ \\
\hline April & $\begin{array}{c}.0208 \\
(5.29)^{* * *}\end{array}$ & $\begin{array}{c}.0399 \\
(4.23)^{* * *}\end{array}$ & $\begin{array}{c}.0597 \\
(4.18)^{* * *}\end{array}$ & $\begin{array}{l}-.0042 \\
(.56)\end{array}$ \\
\hline May & $\begin{array}{c}.0227 \\
(5.76)^{* * *}\end{array}$ & $\begin{array}{c}.0197 \\
(2.09)^{* *}\end{array}$ & $\begin{array}{c}.0425 \\
(2.98)^{* * *}\end{array}$ & $\begin{array}{l}.0082 \\
(1.09)\end{array}$ \\
\hline June & $\begin{array}{c}.0219 \\
(5.57)^{* * *}\end{array}$ & $\begin{array}{c}.0473 \\
(5.05)^{* * *}\end{array}$ & $\begin{array}{c}.0315 \\
(2.21)^{* *}\end{array}$ & $\begin{array}{l}.0007 \\
(.10)\end{array}$ \\
\hline July & $\begin{array}{c}.0262 \\
(6.66)^{* * *}\end{array}$ & $\begin{array}{c}.0275 \\
(2.92)^{* * *}\end{array}$ & $\begin{array}{l}.0138 \\
(.96)\end{array}$ & $\begin{array}{l}.0084 \\
(1.10)\end{array}$ \\
\hline August & $\begin{array}{l}-.0176 \\
(4.45)^{* * *}\end{array}$ & $\begin{array}{c}.0237 \\
(2.49)^{* * *}\end{array}$ & $\begin{array}{c}.0330 \\
(2.30)^{* *}\end{array}$ & $\begin{array}{l}-.0065 \\
(.85)\end{array}$ \\
\hline September & $\begin{array}{l}-.0316 \\
(7.98)^{* * *}\end{array}$ & $\begin{array}{c}.0736 \\
(7.70)^{* * *}\end{array}$ & $\begin{array}{c}.0576 \\
(4.00)^{* * *}\end{array}$ & $\begin{array}{l}-.0072 \\
(.94)\end{array}$ \\
\hline October & $\begin{array}{c}-.0406 \\
(10.25)^{* * *}\end{array}$ & $\begin{array}{c}.0736 \\
(7.75)^{* * *}\end{array}$ & $\begin{array}{c}.0897 \\
(6.25)^{* * *}\end{array}$ & $\begin{array}{l}.0003 \\
(.04)\end{array}$ \\
\hline November & $\begin{array}{l}-.0135 \\
(3.41)^{* * *}\end{array}$ & $\begin{array}{c}.0323 \\
(3.40)^{* * *}\end{array}$ & $\begin{array}{c}.0402 \\
(2.80)^{* * *}\end{array}$ & $\begin{array}{c}.0149 \\
(1.96)^{* *}\end{array}$ \\
\hline December & $\begin{array}{c}-.0193 \\
(4.80)^{* * *}\end{array}$ & $\begin{array}{c}.0275 \\
(2.87)^{* * *}\end{array}$ & $\begin{array}{r}.0248 \\
(1.72)^{*}\end{array}$ & $\begin{array}{l}.0096 \\
(1.26)\end{array}$ \\
\hline B. Portfolio- & sonal Effects & & & \\
\hline $\begin{array}{l}\text { January/ } \\
\text { Portfolio } \\
\text { February/ } \\
\text { Portfolio } \\
\text { March/ } \\
\text { Portfolio }\end{array}$ & $\begin{array}{c}.0000 \\
(2.79)^{* * *} \\
-.0000 \\
(1.45) \\
-.0000 \\
(2.08)^{* *}\end{array}$ & $\begin{array}{c}.0135 \\
(1.92)^{* *} \\
-.0059 \\
(.86) \\
-.0003 \\
(.05)\end{array}$ & $\begin{array}{c}.0044 \\
(1.31) \\
.0174 \\
(.52) \\
.0032 \\
(.95)\end{array}$ & $\begin{array}{c}-.0022 \\
(3.70)^{* * *} \\
-.0013 \\
(2.15)^{* *} \\
-.0000 \\
(.08)\end{array}$ \\
\hline- & - & - & - & - \\
\hline $\begin{array}{l}\text { October/ } \\
\text { Portfolio } \\
\text { November/ } \\
\text { Portfolio }\end{array}$ & $\begin{array}{l}.0000 \\
(1.56) \\
-.0000 \\
(.29)\end{array}$ & $\begin{array}{c}-.0249 \\
(3.52) * * * \\
-.0123 \\
(1.74)^{*}\end{array}$ & $\begin{array}{l}-.0126 \\
(3.78)^{* * *} \\
-.0061 \\
(1.82)^{*}\end{array}$ & $\begin{array}{c}.0027 \\
(4.56)^{* * *} \\
.0010 \\
(1.90)^{* *}\end{array}$ \\
\hline
\end{tabular}


TABLE 6. Tests of Monthly Seasonal and Portfolio-Seasonal Effects in Excess Returns Against the CFMRC Equally Weighted Total Returns Index

\begin{tabular}{lcccc}
\hline $\begin{array}{l}\text { Independent } \\
\text { Variable }\end{array}$ & $\begin{array}{c}\text { Market } \\
\text { Capitalization }\end{array}$ & $\begin{array}{c}\text { Beta } \\
\text { Coefficient }\end{array}$ & $\begin{array}{l}\text { Bond } \\
\text { Rating }\end{array}$ & $\begin{array}{c}\text { TSE-Industry } \\
\text { Classification }\end{array}$ \\
\hline December/ & -.0000 & .0001 & .0012 & .0009 \\
Portfolio & $(.16)$ & $(.04)$ & $(.36)$ & $(1.50)$ \\
$F-$ Statistic & $8.03 * * *$ & $10.36 * * *$ & $9.09 * * *$ & $9.54 * * *$ \\
\hline
\end{tabular}

Note: The table reports the results of dummy OLS regressions for a sample of returns of highly scrutinized firms for 1980 through 1998 time period. Monthly seasonal effects are captured in panel A, which reports coefficients of monthly dummy variables. Portfolio-seasonal effects are captured using interaction terms between the monthly dummies and portfolio formation variables based on market capitalization, beta, bond rating and TSE-industry classification. Regression coefficients for these tests are reported in panel B. Excess returns are calculated using the CFMRC Equally Weighted Total Returns Index. The table reports ordinary $t$-statistics in parentheses below each estimated independent variable and in the final raw $F$-tests of the null hypothesis of no differences across months. $*, * *, * * *$ significant at the $10 \%, 5 \%$ and $1 \%$ level, respectively.

months of the year should have been expected.

Table 6, panel $\mathrm{B}$ also documents a strong positive relationship between beta and January returns, as evidenced by the positive January/beta interaction coefficient. In fact, there is a stronger relationship between beta and January returns than bond rating and January returns. Similar to the bond rating findings, October and November are weak months for the high beta stocks (see the negative October/Portfolio and November/Portfolio interaction coefficients). The relative strength of October and November for the low beta stocks, the corresponding weakness in the returns of the high beta stocks and the statistical significance of the interaction terms for October and November provide further support to the gamesmanship hypothesis.

The January effect is not as pervasive across industry groups as one would have thought, given the evidence in table 6, panel B. Generally, the higher the overall risk of the industry (i.e., the lower the industry classification number assigned in this article), the higher the incidence of a January seasonal, as evidenced by the negative January/TSE-industry classification interaction coefficient. As discussed earlier, industry groups with a rank of 1 to 7 are riskier (in terms of standard deviation of returns) than groups with a rank of 8 to13. October and November returns are significantly different across industries, with the safer 
industries having higher (positive) returns and the riskier industries having lower (negative) returns (see the positive October/Portfolio and November/Portfolio interaction coefficients), as portfolio managers rebalance their portfolios away from risky industries and into safer ones. In fact, we find (not shown here) that October and November are seasonally strong months for such higher quality and safer industries as Utilities and Pipelines. If portfolio managers lock in profits and move to lower risk companies, it is only reasonable that they move into regulated industries that expose them to lower risk. The industries with the strongest Januarys are in order of strength, Paper and Forest, Industrial Products, Consumer Products, Metals and Minerals and Financial Services. The January strength (weakness) of stocks in high (low) risk industries and their corresponding weakness (strength) in OctoberNovember provide yet further support for the gamesmanship hypothesis. All $F$-statistics in this Table are statistically significant at the $1 \%$ level of significance. Thus, here too, we reject the null hypotheses $\mathrm{H}_{0}^{1}$ to $\mathrm{H}_{0}^{4}$. Hypothesis $\mathrm{H}_{0}$ is also rejected from the evidence in table 6 .

Taken together the results from tables 5 and 6 (panels B) show that the January effect is particularly strong for low quality stocks with a high beta in high-risk industries, and weak for high quality stocks with low beta in low risk industries. ${ }^{17}$

\section{Concluding Remarks}

This article has examined whether seasonality is also present in the returns of low risk Canadian firms in safe industries for a sample of firms that are highly scrutinized and visible and used such tests as the foundation to empirically test competing explanations of stock market seasonality, namely, the tax-loss selling hypothesis and the gamesmanship hypothesis. The tests covered the period 1980 to 1998.

17. As some of the firm characteristics used in the article may be liquidity related, we divided our sample into quartiles based on a measure of liquidity (namely, volume/shares outstanding) and re-estimated the article's regressions for each liquidity-based quartile using market-adjusted and risk-adjusted (CAPM-based) excess returns. The results (not reported here but available upon request) did not indicate any consistent variability in excess return seasonality between quartiles suggesting that liquidity-differences was not the reason for this article's findings. We would like to thank an anonymous referee for pointing out these additional tests of robustness of the article's findings. 
The article documents that seasonality in returns is not a phenomenon observed only for small firms' stocks. For a sample of highly scrutinized and visible firms strong seasonality in excess returns is reported. However, the firms in our sample have unusually low excess returns in January and returns adjust upwards over the remainder of the year. The results hold even after we control for various risk differences among the stocks of our sample. Further, this article's findings imply that the January effect is not as pervasive across risk classes and industry sectors as earlier studies using aggregate data have shown it to be. While both small and large stocks exhibit seasonality in Canada, generalizations of the pervasiveness of the January effect in Canada can be misleading. Conclusions to the effect that one can profit by investing in the aggregate market in January can result into returns that severely underperform benchmark portfolios. Generally, only high beta, low bond rating companies, especially in five industry sectors, namely, Paper and Forest, Industrial Products, Consumer Products, Metals and Minerals and Financial Services, experience a strong January effect.

Explanations for observed seasonal patterns in stock returns can be evaluated in light of these findings. The tax-loss selling hypothesis asserts that high returns in January on small firms results from selling pressure at year-end by individuals. We expect no seasonality in the stock price of well-known, generally larger firms, if the hypothesis explains seasonal patterns. However, under the gamesmanship hypothesis, we would expect to see the seasonal pattern reported in this article for highly scrutinized firms. The disaggregated data of this study provided evidence in support of the gamesmanship hypothesis. Whenever a January effect is observed, the last quarter of the year tends to be weak for those companies in our sample that experienced a strong January. The opposite is true when a January effect is not evident. If portfolio managers invest to outperform benchmark portfolios, they will put their money in risky securities at the beginning of the year. However, they do not invest indiscriminately in all stocks. They only invest in risky securities, namely, in companies with a low bond rating and high beta, in generally riskier sectors of the economy. For those companies, in those sectors, January excess returns can be quite high. In such cases, the last quarter of the year is weak, as managers bail out of those stocks in order to lock in profits. As they disinvest from those stocks, managers tend to move to less risky securities pushing up those 
less risky securities' stock prices. As a result, those companies with low risk and high quality, in low risk sectors of the economy, tend to have weak January effect but a strong last quarter of the year, as the gamesmanship hypothesis would predict. The evidence provided in this article is consistent with other Canadian (see Athanassakos and Schnabel [1994]) and US (see Cuny et al. [1996] and Ackert and Athanassakos [2001]) studies of the gamesmanship hypothesis, which used different data bases and methodology to test for the gamesmanship hypothesis and the January effect. Finally, the article has demonstrated that size may not be an important determinant of the January effect. The explanatory power of firm size in previous studies was quite possibly spurious as firm size may have proxied for firm visibility and other omitted risk factors.

\section{References}

Ackert, L., and Athanassakos, G. 2001. Visibility, institutional preferences and agency considerations. Journal of Psychology and Financial Markets 2: 201-209.

Athanassakos, G., and Schnabel, J. 1994. Professional portfolio managers and the January effect: Theory and evidence. Review of Financial Economics: 79-91.

Banz, R. W. 1981. The relationship between return and market value of common stocks. Journal of Financial Economics 9: 3-18.

Beaver, W. H.; McAnally, M. L.; and Stinson, C. H. 1997. The information content of earnings and prices: A simultaneous equation approach. Journal of Accounting and Economics 23: 53-81.

Berges, A.; McConnell, J. J.; and Schlarbaum, G. 1984. The turn-of-the-year in Canada. The Journal of Finance 39 (March): 185-192.

Blume, M., and Friend, I. 1986. Recent and prospective trends in institutional ownership and trading of exchange and OTC stocks. Working Paper. University of Pennsylvania.

Blume, M. E., and Stambaugh, R. F. 1983. Biases in computed returns: An application to the size effect. Journal of Financial Economics 12: 387-404.

Brennan, M. J.; Jagadeesh, N.; and Swaminathan, B. 1993. Investment analysis and the adjustment of stock prices to common information. Review of Financial Studies 6 (Winter): 799-824.

Brennan, M. J., and Subrahmanyam, A. 1995. Investment analysis and price information in securities markets. Journal of Financial Economics 38 (July): 361-381. 
Brown, P.; Kleidon, A. W.; and March, T. A. 1983. Stock return seasonalities and the tax-loss selling hypothesis: Analysis of the arguments and Australian evidence. Journal of Financial Economics 12: 105-127.

Business Week. 1995. You should know what your fund manager is making. (May 22): 116.

Cuny, C.; Fedenia, M.; and Haugen, R. A. 1996. Professional investor re-entry and the January effect. Advances in Financial Economics 2: 47-74.

DeBondt, W. F. M., and Thaler, R. H. 1987. Further evidence on overreaction and stock market seasonality. The Journal of Finance 42 (July): 557-582.

Ederington, L. H., and Goh, J. C. 1998. Bond rating agencies and stock analysts: Who knows what when? Journal of Financial and Quantitative Analysis 33 (December): 569-585.

Ederington, L. H., and Yawitz, J. 1987. The bond rating process. In Handbook of Financial Markets and Institution. $6^{\text {th }}$ ed., E. Altman, (ed.), New York, NY: John Wiley and Sons.

Falkenstein, E. G. 1996. Preferences for stock characteristics as revealed by mutual fund portfolio holdings. Journal of Finance 51 (March): 111-135.

Fama, E., and French, K. 1992. The cross-section of expected stock returns. Journal of Finance: 427-465.

Fama, E., and French, K. 1989. Business conditions and expected returns on stocks and bonds. Journal of Financial Economics 25: 23-50.

Globe and Mail. 1995a. The best families have bad apples, report on business. (May 31): B9.

Globe and Mail. 1995b. Inertia undermines TSE, report on business. (May 31): B11.

Globe and Mail. 1996. Despite rising doubts, mutual fund managers pour cash into stocks. (December 30): B4.

Gultekin, M. N., and Gultekin, N. B. 1983. Stock market seasonality: International evidence. Journal of Financial Economics 12: 469-481.

Hatch, J. E., and White, R. W. 1988. Canadian stocks, bonds, bills and inflation: 1950-1987. The Research Foundation of the Institute of Chartered Financial Analysts. Charlottesville, Virginia.

Haugen, R. A. 1990. Modern Investment Theory. Second Edition, New Jersey: Prentice-Hall, Englewood Cliffs.

Haugen, R. A., and Lakonishok, J. 1988. The incredible January effect: The stock market's unsolved mystery. Illinois: Dow Jones-Irwin.

Jog, V., and Li, B. 1995. Price related anomalies on the Toronto stock exchange. ASAC 1995 Conference Proceedings, Finance Division 16: 135-149.

Judge, G.; Griffiths, W.; Hill, C.; Lutkephol, H.; and Lee, T. 1985. The theory and practice of econometrics. New York: Wiley.

Kato, K., and Schallheim, J. S. 1983. Seasonal and size anomalies in the Japanese stock market. Journal of Financial and Quantitative Analysis 20 (June): 243-259. 
Keim, D. B. 1983. Size-related anomalies and stock return seasonality - Futher empirical evidence. Journal of Financial Economics 12: 13-32.

Kotoulas, G., and Kryzanowski, L. 1996. Macrofactor conditional volatilities, time varying risk premia and stock return behavior. Financial Review 31 (February): 169-195.

Pettengill, G. N.; Sundaram, S.; and Mathur, I. 1995. The conditional relation between beta and returns. Journal of Financial and Quantitative Analysts (March): 101-116.

Reilly, F. K., and Drzycimski, E. 1974. Alternative industry performance risk. Journal of Financial and Quantitative Analysis (June): 423-446.

Reinganum, M. R., 1983. The anomalous stock market behaviour of small firms in January - Empirical tests for tax-loss selling effects. Journal of Financial Economics 12: 89-104.

Ritter, J. R. 1988. The buying and selling behaviour of individual investors at the turn of the year. The Journal of Finance 43 (July): 701-716.

Ritter, J. R. and Chopra, N. 1989. Portfolio rebalancing and the turn-of-the-year. The Journal of Finance 4 (March): 149-166.

Roll, R. 1983. On computing mean returns and the small firm premium. Journal of Financial Economics 12: 371-386.

Rozeff, M. S., and Kinney, W. R. Jr. 1976. Capital market seasonality: The case of stock returns. The Journal of Financial Economics 3: 379-402.

Seyhun, H. N. 1988. The January effect and aggregate insider trading. The Journal of Finance 43 (March): 129-141.

Tinic, S. M.; Barone-Adesi, G.; and West R. R. 1987. Seasonality in Canadian stock prices: A test of the tax-loss-selling hypothesis. Journal of Financial and Quantitative Analysis: 51-64.

Tinic, S. M., and Barone-Adesi, G. 1988. Stock return seasonality and the tests of asset pricing models: Canadian evidence. In Stock Market Anomalies, E. Dimson (ed.), London: Cambridge University Press: 129-146.

Tinic, S. M., and West, R. R. 1986. Risk and return: January vs. the rest of the year. Journal of Financial Economics: 561-574.

Wakerman, L. M. 1990. The real function of bond rating agencies. In The Modern Theory of Corporate Finance, C. W. Smith, Jr. (ed.): 410-415. 